\title{
Effect of Nitrogen Implantation on the Structure and Properties of Austenitic Corrosion-Resistant Steels
}

\section{D.S. Asanova, A.S. Vasiliev, N.N. Ozerets, V.V. Berezovskaya, and M.A. Pavlov}

Ural Federal University named after the first President of Russia B.N.Yeltsin, Russia

\section{Abstract}

Work is devoted to studying the effect of implantation of nitrogen ions into the surface of austenitic stainless steels to improve their functional properties. Four grades of austenitic corrosion-resistant steels 02H16N10M2, 08H15AG10D2, 06H15AG9NM2 and 09H15AG9ND2 were taken after cold plastic deformation and annealing from $680^{\circ} \mathrm{C}$ in water and subsequent implantation with $\mathrm{N}+$ ions with different radiation dose: $0,01 \mathrm{n}$ $0,1 \%$. It was found that irradiation of austenitic stainless steels with nitrogen ions can be considered an effective way to increase the hardness and yield strength of steels in the operation in a corrosive environment.

Corresponding Author:

N.N. Ozerets

ozerets@mail.ru

Received: 25 February 2019

Accepted: 9 April 2019

Published: 15 April 2019

Publishing services provided by

Knowledge E

(c) D.S. Asanova et al. This article is distributed under the terms of the Creative Commons

Attribution License, which permits unrestricted use and redistribution provided that the original author and source are credited.

Selection and Peer-review under the responsibility of The Ural school-seminar of metal scientists-young researchers Conference Committee.
Keywords: steel, austenite, nitrogen implantation, hardness, corrosion resistance.

\section{Introduction}

The development of technology imposes requirements for increased strength and efficiency to steels in various fields of application. During the last 20-30 years, considerable attention in our country and abroad has been paid to the problem of ionic modification of the surfaces of structural materials. Compared with traditional methods of chemical-heat treatment, ion implantation allows to reduce the time by tens of times and dramatically reduce the processing temperature, as well as improve the protective and strength properties of products [1-3].

The aim of this work is to study the possible mechanisms of structure formation, phase composition, physical-mechanical and service properties of austenitic steels of different composition after bombardment with nitrogen ions $\mathrm{N}+$.

\section{Research Methodology}

Four grades of corrosion-resistant steels (02H16N10M2, 08H15AG10D2, 06H15AG9NM2

G OPEN ACCESS and 09H15AG9ND2) were investigated. The samples for the study were cut from a thin 
$(1 \mathrm{~mm})$ sheet obtained by cold rolling, followed by annealing at $680^{\circ} \mathrm{C}$ and implantation with $\mathrm{N}^{+}$ions with different radiation doses $(0.01 \%$ - irradiation regime $1,0.1 \%$ - irradiation regime 2). After irradiation, the samples were subjected to recrystallization annealing at a temperature of $300^{\circ} \mathrm{C}$ for 1 hour. The chemical composition of steel is given in table 1.

TABLE 1: The chemical composition of the investigated steels.

\begin{tabular}{|c|c|c|c|c|c|c|c|c|c|c|c|}
\hline $\begin{array}{l}\text { Steel grade (№ } \\
\text { sample) }\end{array}$ & Class & C & Si & $\mathrm{Mn}$ & $\mathrm{S}$ & $P$ & $\mathrm{Cr}$ & $\mathrm{Ni}$ & Mo & $\mathrm{Cu}$ & $\mathrm{N}$ \\
\hline $02 \mathrm{H} 16 \mathrm{~N} 10 \mathrm{M} 2$ (2) & Austenite & 0.018 & 0.51 & 1.38 & 0.001 & 0.023 & 16.12 & 10.17 & 2.04 & - & 0.037 \\
\hline $\begin{array}{l}\text { 08H15AG10D2 } \\
\text { (5) }\end{array}$ & Austenite & 0.08 & 0.32 & 9.78 & 0.002 & 0.030 & 14.5 & 0.16 & - & 1.62 & 0.163 \\
\hline $\begin{array}{l}\text { 06H15AG9NM2 } \\
\text { (6) }\end{array}$ & Austenite & 0.06 & 0.32 & 9.20 & 0.003 & 0.025 & 14.8 & 0.95 & 1.68 & - & 0.166 \\
\hline $\begin{array}{l}\text { O9H15AG9ND2 } \\
\text { (15) }\end{array}$ & Austenite & 0.094 & 0.34 & 8.98 & 0.005 & 0.060 & 15.35 & 1.16 & 0.10 & 1.66 & 0.1330 \\
\hline
\end{tabular}

To solve this goal, an ion implantation unit was used to double-irradiate samples with a gas ion beam with an energy of up to $40 \mathrm{keV}$. Mechanical testing of samples for uniaxial tension was performed according to GOST 11701-84 using a TiniusOlsenH50KS machine. The microstructure of the steel was investigated on a metallographic inverted digital complex Axio Zoom V16 manufactured by Carl Zeiss using an image analysis program SIAMS 700. The hardness was determined on a Vickers instrument with a load of 0.049 $\mathrm{kN}$. X-ray structural method was used to determine the phase composition of steels and lattice parameters. The survey was performed on an XRD-7000 X-ray diffractometer.

\section{Research Results}

The microstructure of the investigated steels is a fine-grained twinned austenite. According to the results of X-ray structural studies, the structure of the steel in the initial state (after cold rolling and quenching from $1050^{\circ} \mathrm{C}$ in water) consisted only of austenite, within the accuracy of the method.

The mechanical properties of the steels are given in Table 2. Steel 02H16N10M2 has the lowest strength and ductility, in which the nitrogen content is significantly lower than in other steels. The highest properties showed 08H15AG10D2 and 09H15AG9ND2 steels, which, in addition to nitrogen, contain copper.

The microstructure of all the investigated steels after irradiation regime 1 and recrystallization revealed some grinding of austenite grain. The structure of steels $02 \mathrm{H} 16 \mathrm{~N} 10 \mathrm{M} 2$ and 08H15AG10D2 changed little under the action of irradiation (Figures 1, 2; a, b), as did the austenitic structure with ultrafine grains $(2-4 \mu \mathrm{m})$ in 09H15AG9ND2 steel (Figure 
TABLE 2: Mechanical properties of steel.

\begin{tabular}{|c|c|c|c|c|c|c|}
\hline $\begin{array}{l}\text { № } \\
\text { sample }\end{array}$ & Steel grade & $\begin{array}{l}\text { Irradiation } \\
\text { regime }\end{array}$ & $\sigma_{\text {yield }},[\mathrm{MPa}]$ & $\sigma_{u t s},[\mathrm{MPa}]$ & $\delta, \%$ & $\psi, \%$ \\
\hline \multirow[t]{3}{*}{2} & O2H16N10M2 & - & 220 & 580 & 31 & 40 \\
\hline & & 1 & 280 & 650 & 21 & 30 \\
\hline & & 2 & 280 & 640 & 37 & 42 \\
\hline \multirow[t]{3}{*}{5} & 08H15AG10D2 & - & 520 & 1050 & 39 & 40 \\
\hline & & 1 & 450 & 840 & 22 & 23 \\
\hline & & 2 & 470 & 1130 & 46 & 25 \\
\hline \multirow[t]{3}{*}{6} & 06H15AG9NM2 & - & 370 & 870 & 43 & 42 \\
\hline & & 1 & 330 & 730 & 27 & 27 \\
\hline & & 2 & 360 & 930 & 49 & 41 \\
\hline \multirow[t]{3}{*}{15} & 09H15AG9ND2 & - & 510 & 970 & 37 & 40 \\
\hline & & 1 & 490 & 880 & 23 & 24 \\
\hline & & 2 & 460 & 980 & 48 & 41 \\
\hline
\end{tabular}

1, 2; d). In steel 06H15AG9NM2, austenite was observed with annealing twins, but with a larger grain.

Further grinding of austenite grain after the bombardment with nitrogen ions in regime 2 was not observed (Figure 2). In all samples, after irradiation, an increase in strength was observed without a significant change in plasticity, as well as in hardness, which is associated with an increase in the density of defects and the appearance of deformation martensite (Figure 3).

\section{Conclusions}

1. In the studied steels after ion implantation, an increase in the mechanical characteristics of the alloy is observed: hardness HV on average by 1.5-2 times, $\sigma_{u t s}-$ by $50-60 \%$. The increase in $\mathrm{HV}$ and $\sigma_{u t s}$ is due to an increase in the concentration of defects in the alloy structure.

2. The yield strength $\left(\sigma_{\text {yield }}\right)$ of the investigated steels during the implantation of $\mathrm{N}^{+}$ ions increases on average by $10-20 \%$. Its increase depends on the method of implantation and the degree of deformational aging of steels, in particular, as a result of copper extraction, as in samples 5 and 15. 

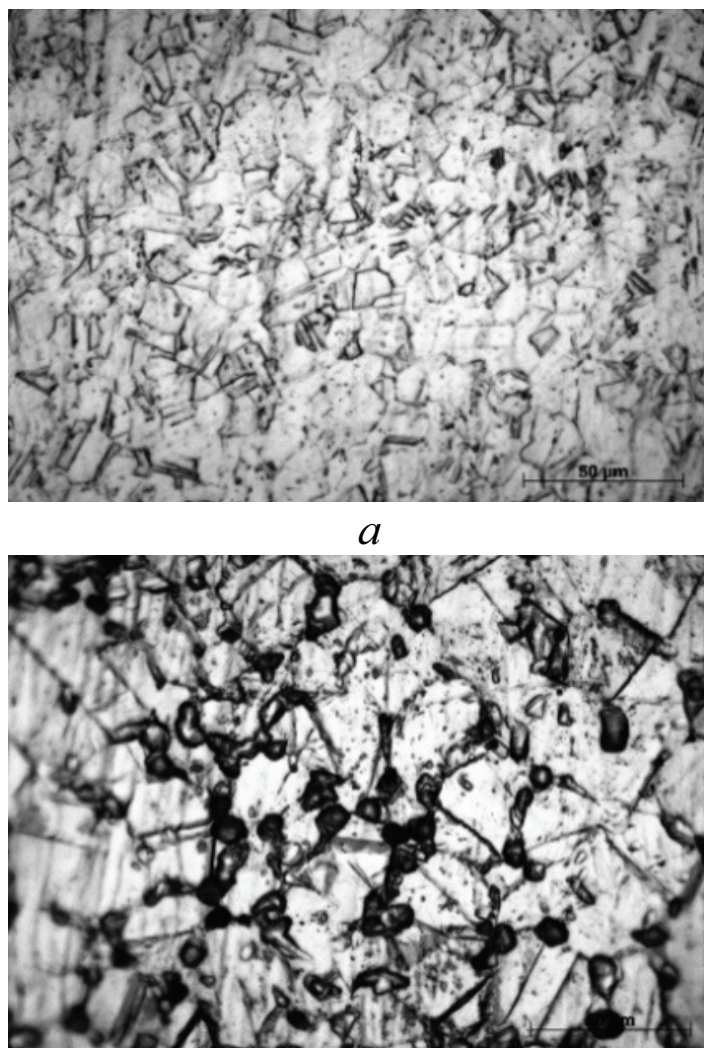

$c$

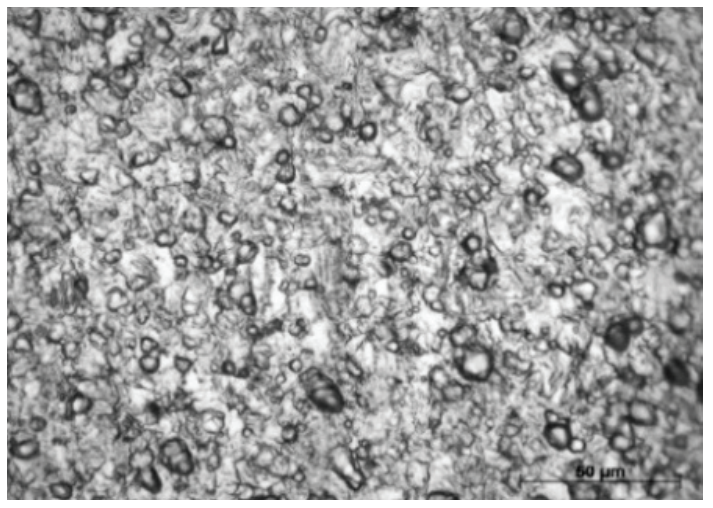

$b$

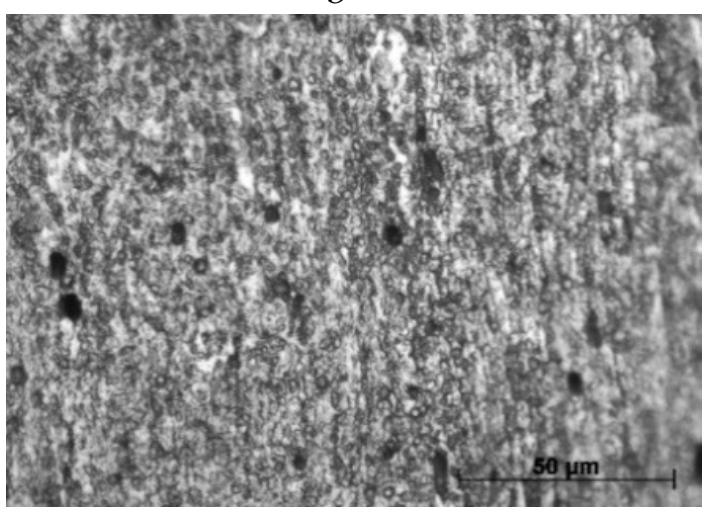

$d$

Figure 1: The microstructure of the steel after irradiation regime 1: $a$ - steel № $2 ; b-$ steel № $5 ; c-$ steel № 6 ; $d$ - steel № 15.

3. The grain size of austenite after implantation, accompanied by heating to $70-250$

${ }^{\circ} \mathrm{C}$, in all steels decreases due to the fragmentation of the grains with increasing dislocation density.

4. Irradiation with nitrogen ions of austenitic corrosion-resistant steels can be considered effective for enhancing the mechanical properties during operation in air and in a corrosive environment.

\section{References}

[1] Kalin B. A. Radiatsionno-puchkovyye tekhnologii obrabotki konstruktsionnykh materialov / B. A. Kalin // Fizika i khimiya obrabotki materialov. 2001, № 4. P. 5-16.

[2] Goncharov V. V. Mikrotverdost' poverkhnosti nerzhaveyushchey stali, modifitsirovannoy ionnoy implantatsii // Problemy mashinostroyeniya, 2013, T. 16, № 6. P. 47-51.

[3] Budzinski P., Polyanski K., Kobzev A.P. Izmeneniye svoystv poverkhnosti nerzhaveyushchey marki AISI316L, implantirovannoy azotom // Poverkhnost'. 

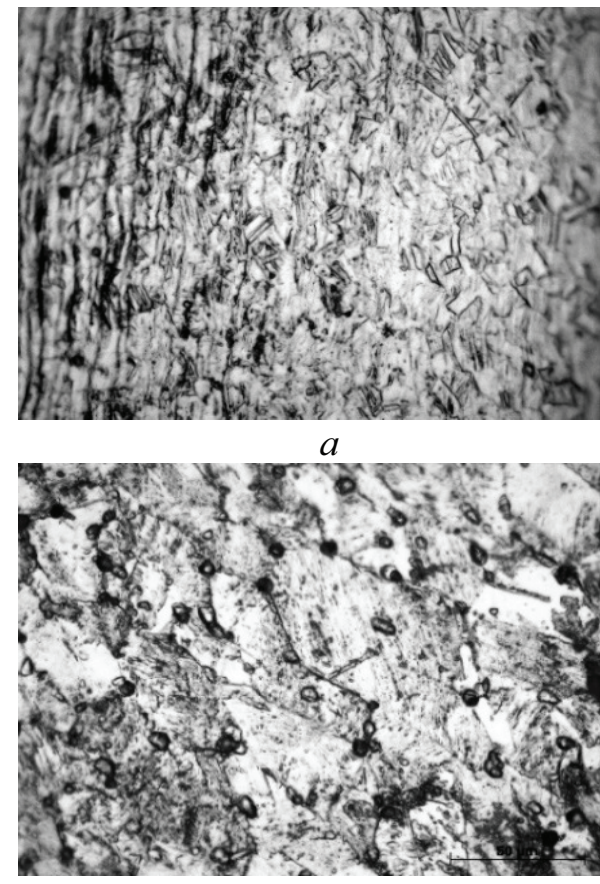

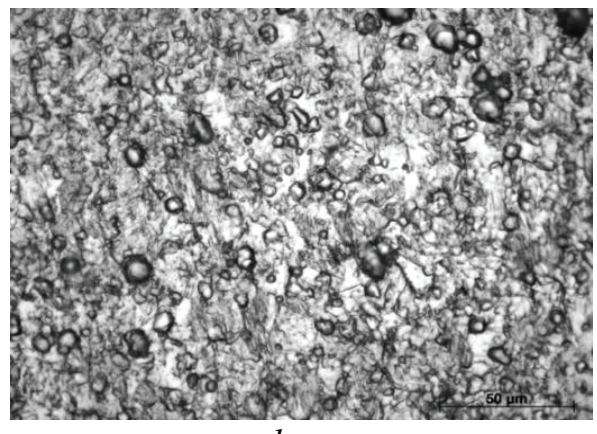

$b$

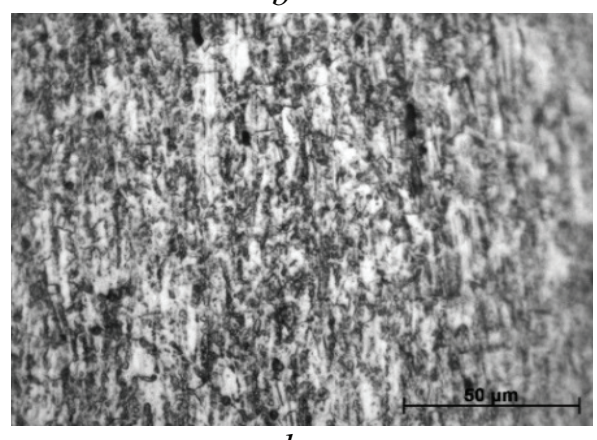

$d$

Figure 2: The microstructure of the steel after irradiation regime $2: a-$ steel № $2 ; b-$ steel № $5 ; c-$ steel № $6 ; d$ - steel № 15 .
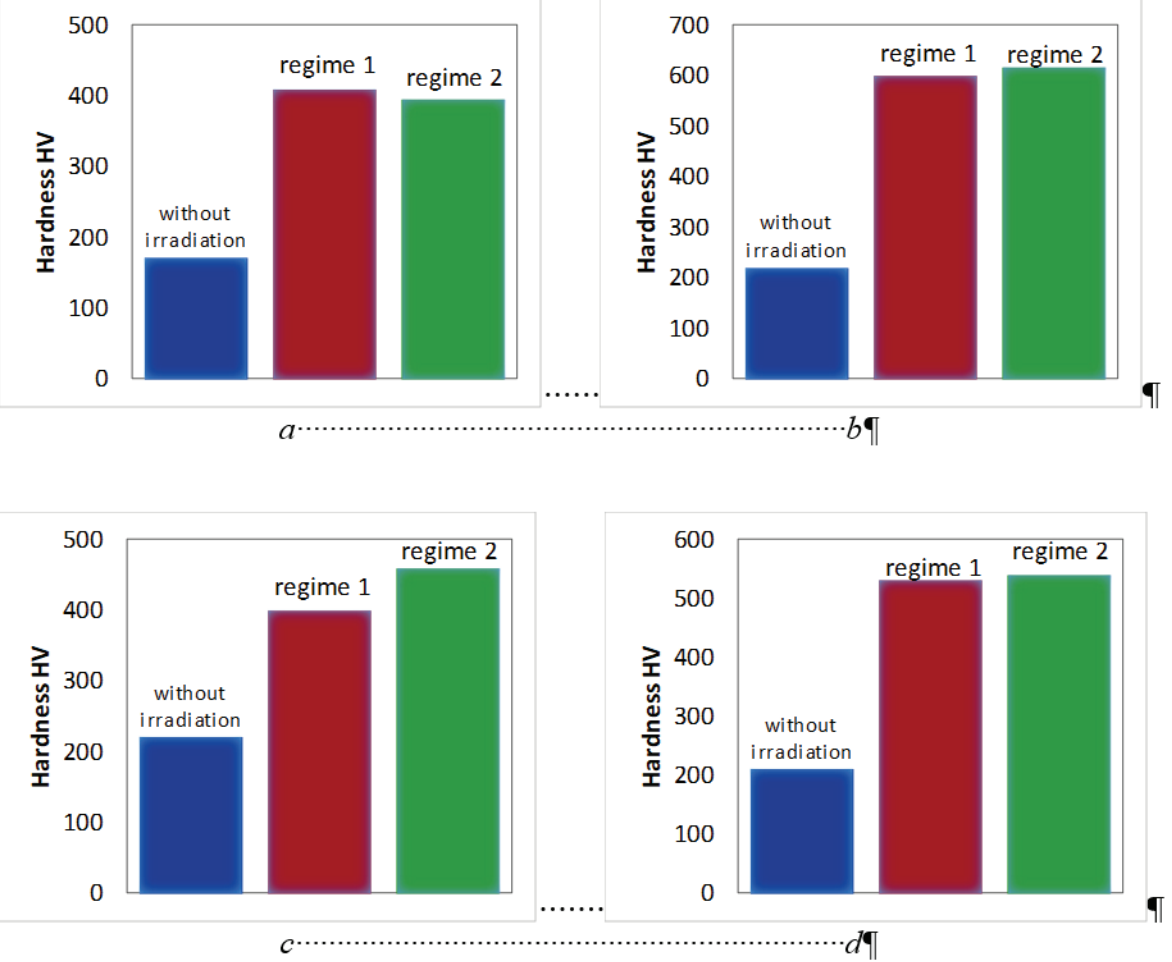

Figure 3: Steel hardness before and after irradiation: $a$ - steel № 2; $b$ - steel № 5; c - steel № 6; $d$ - steel № 15.

Rentgenovskiye, sinkhrotronnyye i neytronnyye issledovaniya. 2008, № 8. P. 80-85. 
[4] Povysheniye iznosostoykosti stali 30KHGSN2A implantatsii ionov azota i ionov metalla / A. A. Yarnykh [i dr.] // Materialovedeniye. 2014. № 11. P. 30-34. 